\title{
Dust emissions over the Sahel associated with the West African monsoon intertropical discontinuity region: A representative case-study
}

\author{
D. Bou Karam, ${ }^{\text {a* C. Flamant, }},{ }^{\mathrm{a}}$ P. Knippertz, ${ }^{\mathrm{b}}$ O. Reitebuch, ${ }^{\mathrm{c}}$ J. Pelon, ${ }^{\mathrm{a}}$ M. Chong ${ }^{\mathrm{d}}$ \\ and A. Dabas ${ }^{\mathrm{e}}$ \\ a Université Pierre et Marie Curie, Service d'Aéronomie/Institut Pierre-Simon Laplace, Paris, France \\ ${ }^{\mathrm{b}}$ Institut für Physik der Atmosphäre, Johannes Gutenberg-Universität Mainz, Germany \\ ${ }^{c}$ Deutsches Zentrum für Luft- und Raumfahrt DLR, Oberpfaffenhofen, Germany \\ ${ }^{\mathrm{d}}$ Université de Toulouse, Laboratoire d'Aérologie, Toulouse, France \\ ${ }^{\text {e }}$ Centre National de Recherches Météorologiques (Météo-France/CNRS), Toulouse, France
}

\begin{abstract}
Near-dawn airborne lidar and dropsonde observations acquired on 7 July 2006, during the African Monsoon Multidisciplinary Analysis (AMMA) Special Observing Period 2a1, were used to investigate dust mobilization, lifting and transport in the intertropical discontinuity (ITD) region over western Niger. Atmospheric reflectivity data from the LEANDRE 2 lidar system enabled us to analyse the structure of dust plumes in the context of wind and thermodynamic information provided by the WIND lidar system and dropsondes. Dust mobilization was mainly observed in two locations: (a) within the monsoon flow as the result of the passage of a density current originating from a mesoscale convective system over southwest Niger, and (b) at the leading edge of the monsoon flow where the near-surface winds and turbulence were strong, because the monsoon flow was behaving as an intrusive density current. The circulation in the head of the monsoon density current lifted the mobilized dust towards the wake, along an isentropic surface. Behind and away from the leading edge, some of the mobilized dust was observed to mix across the monsoon-harmattan interface, due to the existence of mechanical shear above the monsoon layer. The dust thus becomes available for long-range transport by the harmattan. Because dust sources are widespread over the Sahel and presumably active on many days when the ITD is located in this region during summer, dust emissions associated with the described mechanism may influence the radiation budget over West Africa. Copyright @ 2008 Royal Meteorological Society
\end{abstract}

KEY WORDS AMMA; harmattan; density current; airborne lidars; dropsondes; ECMWF analyses

Received 19 November 2007; Revised 8 February 2008; Accepted 10 March 2008

\section{Introduction}

The impact of dust on the climate system and the large uncertainties associated with the role of dust in the Earth's radiation budget is now widely recognized (e.g. Intergovernmental Panel on Climate Change, IPCC 2001, 2007). West Africa is the world's largest source of mineral dust. Satellite sensors consistently indicate that dust aerosol plumes are the most widespread, persistent and dense found on Earth (e.g. Prospero et al., 2002). The radiative effects of dust (both direct and indirect) can modify the general circulation at climate time-scales (e.g. Yoshioka et al., 2007), but also at shorter (synoptic) time-scales (e.g. Tompkins et al., 2005a).

Dust emissions from West Africa follow a distinct annual cycle and are connected with the occurrence of

\footnotetext{
* Correspondence to: D. Bou Karam, Service d'Aéronomie, Institut Pierre-Simon Laplace, Tour 45, Boite 102, Université Pierre et Marie Curie, 4 Place Jussieu, 75252 Paris Cedex 05, France.

E-mail: diana@aero.jussieu.fr
}

high wind speeds at the surface. Satellite-based climatological studies (e.g. Evan et al., 2006) have demonstrated that dust exports from the Sahara during winter are associated with strong harmattan winds and take place in discrete outbreaks of several days duration. In contrast, the summer season is prone to high dust activity and is the period when most of the intense dust outbreaks over the North Atlantic occur (Engelstaedter and Washington, 2007).

Occasional strong dust outbreaks have been documented to be associated with the penetration of an upperlevel trough to low latitudes (e.g. Jankowiak and Tanré, 1992), with low-level cold fronts (e.g. Alpert and Ganor, 1993) or with density currents caused by evaporational cooling along precipitating cloud-bands over the northern Sahara (Knippertz and Fink, 2006) and along the Sahara side of the Atlas Mountain chain in southern Morocco (Knippertz et al., 2007). Figure 1(d) provides details of orographic features. In the Bodélé Depression, dust outbreaks have been reported in association with strong surface winds generally occurring after sunrise, as 
(a)

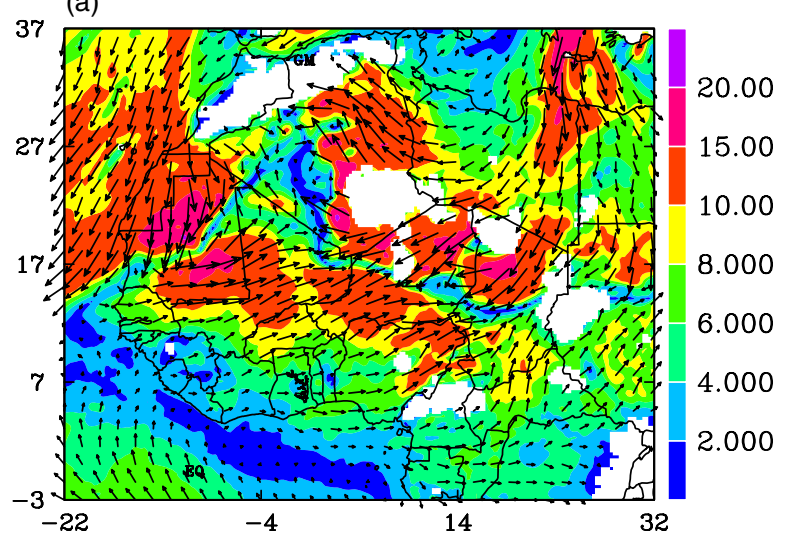

(c)

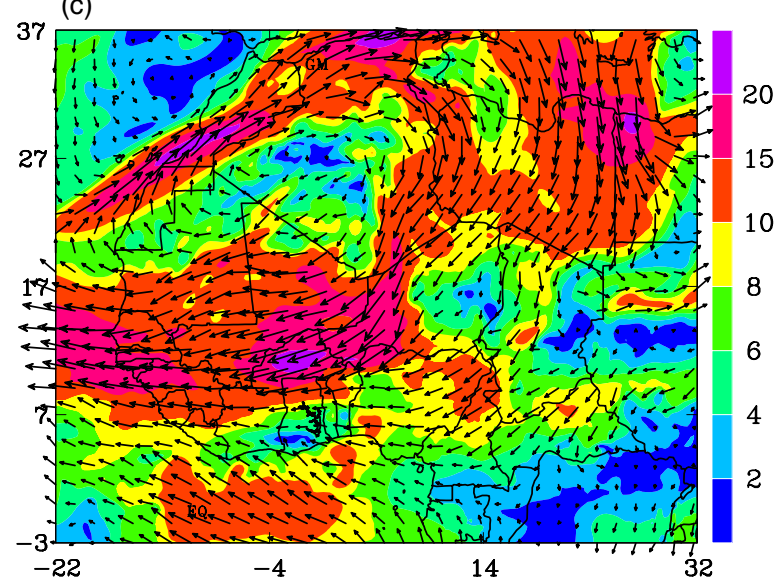

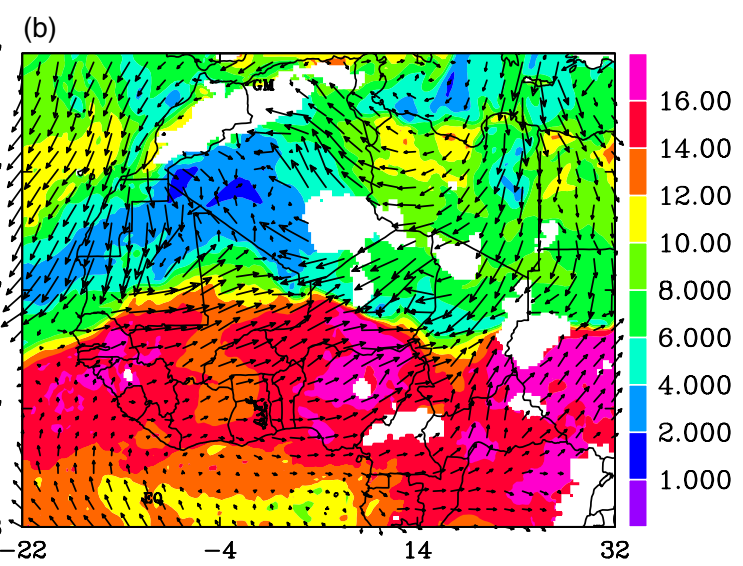

(d)

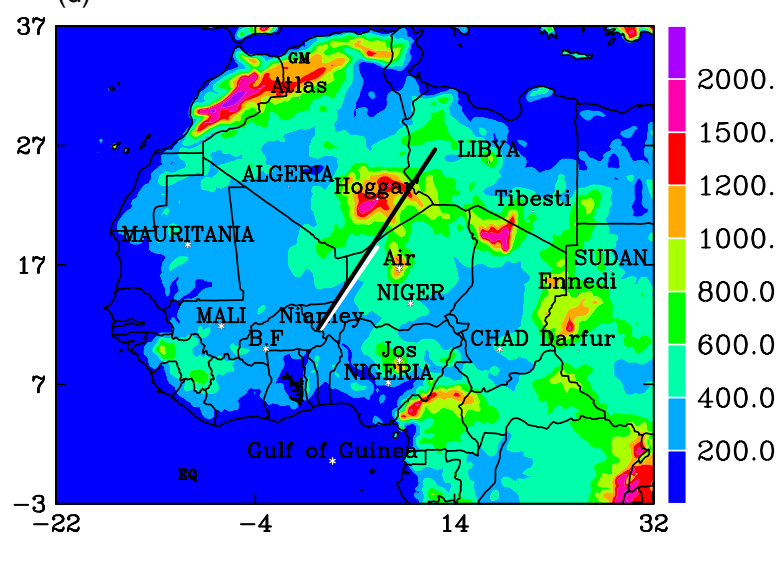

Figure 1. ECMWF analysis on 7 July 2006 at 0600 UTC showing (a) wind speed (colour, $\mathrm{m} \mathrm{s}^{-1}$ ) and direction (arrows) at 925 hPa, (b) water vapour mixing ratio (colour, $\mathrm{g} \mathrm{kg}^{-1}$ ) and wind direction (arrows) at $925 \mathrm{hPa}$ and (c) wind speed (colour, $\mathrm{m} \mathrm{s}^{-1}$ ) and direction (arrows) at $600 \mathrm{hPa}$. (d) shows the main geographic and orographic features mentioned in the text. The solid white line represents the F/F20 and D/F20 flight tracks on 7 July 2006, and the solid black line indicates the location of the vertical cross-sections shown in Figure 2. This figure is available in colour online at www.interscience.wiley.com/qj

turbulence in the growing planetary boundary layer (PBL) mixes the momentum of the nocturnal low-level jet downward. This jet forms above the radiatively cooled surface layer in the lee of the constriction between the Ennedi and the Tibesti uplands (e.g. Washington and Todd, 2005) and decays in the course of the day (Todd et al., 2008). Over the Sahel, propagating mesoscale convective systems (MCSs), and their associated density currents, offer the most efficient mechanism for dust lifting and injection to altitudes favourable for long-range transport, particularly at the beginning of the monsoon season, before the growing vegetation rapidly inhibits local dust emission (e.g. Sterk, 2002; Flamant et al., 2007).

Recently, using a satellite-derived dust index and reanalysed atmospheric fields, Engelstaedter and Washington (2007) have shown that the annual dust cycle in the West African dust hot spots is not related to changes in mean surface wind strength, but is linked to smallscale high-wind events. They put forward evidence that the dust loads over West Africa are highest around the monsoon onset period in June, in coincidence with the northward displacement of the intertropical discontinuity (ITD, the near-surface position of the interface between the monsoon and the harmattan, referred to as the 'convergence zone on the northward bound' of the ITCZ by Engelstaedter and Washington, 2007) to dust hot spots in the Sahel.

In this study we present observational evidence of dust emission over western Niger associated with the winds and turbulence existing along the leading edge of the monsoon flow in the ITD region. The dust emissions were observed shortly after sunrise, when the nocturnal monsoon flow was still behaving as an intruding density current advancing into the harmattan flow. (Summer monsoons, in essence, are giant seabreeze systems. It is well known that atmospheric density currents are fitting descriptions of sea-breeze fronts, e.g. Reible et al., 1983; Simpson, 1987. A density current is an intrusion of a denser fluid beneath a lighter fluid, due mainly to the hydrostatic forces arising from gravity and the density differences.) The region over which the dust emissions were documented (i.e. to the south of the Hoggar and to the west of the Aïr Mountains) is characterized by the existence of a huge system of ephemeral rivers and streams that drain the Hoggar and Aïr massifs, thereby defining a complex array of dust 
sources consisting of fluvial deposits. A recent study by Schepanski et al. (2007), based on the Meteosat Second Generation (MSG) Spinning Enhanced Visible and InfraRed Imager (SEVIRI) dust index, has shown that this area is a prominent dust source in the summer season, being located in the vicinity of mountain foothills where fluvial sediment provides fine material for deflation.

Airborne observations used here (a combination of backscatter and Doppler wind lidars, as well as dropsonde measurements) were acquired in the framework of the African Monsoon Multidisciplinary Analysis (AMMA; Redelsperger et al., 2006) Special Observing Period (SOP), during the month of July 2006. Even though this paper focuses on observations gathered on 7 July 2006, evidence of dust emission at the leading edge of the monsoon flow was also found during two other missions on 3 and 10 July 2007 (not shown). To the best of the authors' knowledge, the airborne lidar and dropsonde measurements presented in this paper are the first to be obtained in the remote region of western Niger. It is also the first comprehensive observational study of the impact of the monsoon leading edge on aerosol vertical distribution in the ITD region.

The remainder of the paper is organized as follows. In Section 2, the data used in this paper as well as the airborne operations on 7 July 2006 are presented. The synoptic situation is described in Section 3. Section 4 provides an overview of the vertical structure of the atmosphere across the ITD. Dust mobilization, mixing and transport in the ITD region are detailed in Section 5. The paper concludes with a discussion in Section 6 .

\section{Data}

On 7 July 2006, an 'ITD survey' mission was conducted using two aircraft, namely the Service des Avions Français Instrumentés pour la Recherche en Environnement (SAFIRE) Falcon 20 and the Deutsches Zentrum für Luft- und Raumfahrt (DLR) Falcon 20 (hereafter F/F20 and D/F20, respectively). Both aircrafts flew at approximately $8 \mathrm{~km}$ above mean sea level (amsl) from Niamey $\left(2.16^{\circ} \mathrm{E} ; 13.5^{\circ} \mathrm{N}\right)$ to a waypoint close to the Algerian border located at $7^{\circ} \mathrm{E} ; 20^{\circ} \mathrm{N}$, i.e. across the ITD (Figure 1(d)). The mission was performed in the early morning between 0600 and 0900 UTC (between 0700 and 1000 LT, i.e. shortly after sunrise which was around 0545 LT in the region of operations), when the monsoon flow is typically strong and the ITD is well marked.

The objective of the mission was to document the vertical structure of the Saharan PBL and the aerosol distribution, as well as the structure of the ITD, using the high-resolution (both horizontal and vertical) lidarderived atmospheric reflectivity and horizontal wind vector fields, together with temperature, water vapour and wind profiles derived from dropsondes.

The D/F20 was equipped with the airborne Wind INfrared Doppler lidar (WIND; Werner et al., 2001; Reitebuch et al., 2001). The airborne WIND lidar operates at a laser wavelength of $10.6 \mu \mathrm{m}$ and is thus sensitive to large aerosol particles in the $\mu \mathrm{m}$ range. The vertical profile of the horizontal wind vector is determined by a conical scan using the Velocity Azimuth Display (VAD) technique. The vertical and horizontal resolutions of the wind field are $250 \mathrm{~m}$ and about $4 \mathrm{~km}$, respectively. The accuracy of wind estimates depends on the aerosol loading of the atmospheric layers sounded by the lidar, and varies from about $0.5 \mathrm{~m} \mathrm{~s}^{-1}$ (high aerosol loading) to about $2 \mathrm{~m} \mathrm{~s}^{-1}$ at worst (weak aerosol loading).

The F/F20 was equipped with the airborne differential absorption lidar LEANDRE 2 (Bruneau et al., 2001; Flamant et al., 2007) and a 4-channel dropsonde system, the Airborne Vertical Atmospheric Profiling System (AVAPS). The high-resolution (15 $\mathrm{m}$ in the vertical and $1.5 \mathrm{~km}$ in the horizontal) lidar-derived atmospheric reflectivity (at $730 \mathrm{~nm}$ ) is mostly sensitive to aerosols with radii ranging from 0.1 to $5 \mu \mathrm{m}$, and hence to dust aerosols (e.g. Flamant et al., 2007). Furthermore, reflectivity is sensitive to aerosol optical properties and concentration, as well as relative humidity in the case of hygroscopic aerosols. However, over the African continent, close to the sources, desert dust particles are generally considered to be hygrophobic (e.g. Fan et al., 2004). Therefore, reflectivity associated with desert dust is generally not expected to be sensitive to relative humidity fluctuations.

Ten dropsondes were released during the mission by the F/F20, four on the way to northern Niger and six on the way back to Niamey (Table I). The dropsonde data have been processed with the latest release of the Atmospheric Sounding Processing Environment (ASPEN) software (version 2.6.5 of July 2006). In addition to providing information on the temperature and water vapour fields, dropsonde data were used to compute the vertical profiles of the bulk Richardson number to assess where mechanical shear-induced turbulence was important. The bulk Richardson number was computed as

$$
R_{\mathrm{b}}=\left(\frac{g}{T_{\mathrm{v}}}\right) \frac{\Delta \theta_{\mathrm{v}} \Delta z}{\left(\Delta U^{2}+\Delta V^{2}\right)},
$$

Table I. Dropsonde release times and positions along the F/F20 flight track on 7 July 2006.

\begin{tabular}{|c|c|c|c|c|c|c|c|c|c|c|}
\hline Dropsonde & 1 & 2 & 3 & 4 & 5 & 6 & 7 & 8 & 9 & 10 \\
\hline Time (UTC) & 0614 & 0629 & 0644 & 0714 & 0725 & 0730 & 0737 & 0751 & 0806 & 0820 \\
\hline Latitude $\left({ }^{\circ} \mathrm{N}\right)$ & 15.18 & 16.41 & 17.59 & 20.00 & 19.30 & 18.79 & 18.18 & 16.98 & 15.75 & 14.56 \\
\hline Longitude $\left({ }^{\circ} \mathrm{E}\right)$ & 3.42 & 4.33 & 5.20 & 7.00 & 6.47 & 6.10 & 5.65 & 4.75 & 3.85 & 2.96 \\
\hline
\end{tabular}


where $g$ is gravitational acceleration, $T_{\mathrm{v}}$ is absolute virtual temperature, $\Delta \theta_{\mathrm{v}}$ is the virtual potential temperature difference across a layer of thickness $\Delta z$, and $\Delta U$ and $\Delta V$ are the changes in horizontal wind components across that same layer.

Dropsonde-derived near-surface measurements were also used to estimate the theoretical depth and speed of the monsoon leading edge in an idealized density current framework. The depth and speed of a steady-state density current moving into an unstratified atmosphere with no vertical wind shear may be expressed as (Simpson 1987; Koch et al. 1991)

$$
d_{\mathrm{gc}}=\frac{\theta_{\mathrm{vc}} \Delta p}{\rho_{\mathrm{w}} g\left\{\left(p_{\mathrm{c}}-p_{\mathrm{w}}\right) \theta_{\mathrm{vw}}-\theta_{\mathrm{vc}}\right\}},
$$

and

$$
C_{\mathrm{gc}}=\operatorname{Fr}\left(\frac{\Delta p}{\rho_{\mathrm{w}}}\right)^{1 / 2},
$$

where $p$ is pressure, $\rho$ is air density and $F r$ is the Froude number. Subscripts $w$ and $c$ refer to warm and cold air masses, respectively, i.e. ahead of and behind the leading edge of the density current.

Complementary analyses from the European Centre for Medium-range Weather Forecasts (ECMWF) as well as ground-based and satellite observations were also used. In particular, dust storms were identified over North and West Africa using MSG/SEVIRI images produced from a combination of three infrared channels, namely channel $10(12 \mu \mathrm{m})$, channel $9(10.8 \mu \mathrm{m})$ and channel 7 $(8.7 \mu \mathrm{m})$. We shall not show any data from groundbased stations as no SYNOP data from the stations of the meteorological services of Niger and Mali were available on that day. A short discussion on density currents propagating north of Niamey on 7 July will be provided on the basis of the surface measurements made in Agoufou, Mali $\left(1.48^{\circ} \mathrm{W} ; 15.34^{\circ} \mathrm{N}\right)$.

\section{Synoptic situation on 7 July 2006}

Prevailing meteorological conditions over West Africa at 0600 UTC on 7 July 2006 are illustrated using the ECMWF analyses (Figure 1). At $925 \mathrm{hPa}$, the southern half of West Africa was under the influence of the southwest monsoon, while to the north, the wind field was under the influence of the Libyan high and was modulated by the topography. Strong northerly winds were seen over Libya, which were deflected around the northern flank of the Hoggar towards the Atlas (Figure 1(a)). Strong northeasterly winds blew between the Tibesti and Ennedi Mountains in Chad, and over the Bodélé Depression, an area known to be one of the world's most productive dust sources. Niger was under the influence of strong opposing winds, separated by a northwest-southeast oriented line of weak winds corresponding to the ITD (Figure 1(a)); strong southwesterly winds associated with the monsoon flow were seen north of Niamey just east of the Mali-Niger border, while strong northeasterly winds were observed to the north of the ITD, in the lee of the constriction between the Tibesti and Hoggar massifs, as well as between the Aïr and Hoggar massifs. As a result, a sharp gradient of water vapour mixing ratio was observed at $925 \mathrm{hPa}$ across the ITD over Niger (Figure 1(b)), with high moisture values to the southwest (in excess of $14 \mathrm{~g} \mathrm{~kg}^{-1}$ ) and drier conditions to the northeast (less than $6 \mathrm{~g} \mathrm{~kg}^{-1}$ ). At higher levels (600 hPa, Figure 1(c)), western Niger was under the influence of the African Easterly Jet (AEJ), which covered most of the Sahel and Soudanian zones. The AEJ intensity was moderate in the analysis $\left(15-20 \mathrm{~m} \mathrm{~s}^{-1}\right)$, with a maximum over Burkina Faso. Over western Niger, the AEJ exhibited a marked northeasterly component, in connection with the broad anticyclonic circulation above the Saharan heat low (Figure 1(c); Lavaysse et al., 2008).

\section{Vertical structure of the atmosphere across the ITD from observations and analyses}

\subsection{Large-scale picture from ECMWF analyses}

Figure 2 shows vertical cross-sections of potential temperature, water vapour mixing ratio and wind fields extracted from the ECMWF analysis on 7 July 2006 at 0600 UTC along the F/F20 and D/F20 track, between $12^{\circ} \mathrm{N}$ and $28^{\circ} \mathrm{N}$ (i.e. extented to the north with respect to the aircraft track, Figure 1(d)). The section crosses the topography to the north of the Airr, over the Djado Plateau, between the Hoggar and the Tibesti massifs.

Figure 2 suggests that, along the aircraft flight track, the ITD was located at about $18.5^{\circ} \mathrm{N}$, as delineated by the wind reversal at low level, characteristic of the transition from the monsoon to the harmattan flow (Figure 1(a)). Strong near-surface convergence and a strong updraught reaching approximately $6 \mathrm{~km}$ amsl are seen at the ITD. North of the ITD the northeasterly flow interacts with the topography resulting in strong downslope winds below $2 \mathrm{~km}$ amsl in the northern and southern parts of the Hoggar.

The upper-level flow is also quite perturbed by the orography. As a result, the potential temperature and water vapour mixing ratio fields exhibit a large horizontal variability. Just to the north of the ITD, a tongue of dry, warm air is seen to extend towards the surface, reaching down to $1 \mathrm{~km}$ amsl as the result of the interaction between the northeasterly flow and the topography. Hence, the moist monsoon air is separated from the dry northerly air by an even drier air mass. South of the ITD, the isentropes are sloping upward (Figure 2(a)). A similar behaviour is seen in the water vapour mixing ratio field (Figure 2(b)). Though the sloping is similar, the potential temperature is increasing with height whereas the water vapour mixing ratio is decreasing. The ECMWF analysis suggests the existence of a closed circulation south of the leading edge of the monsoon flow, roughly centred at $17^{\circ} \mathrm{N}$, reminiscent of the circulation observed in density current heads (e.g. Goff, 1976; Simpson, 1987). 
(a)

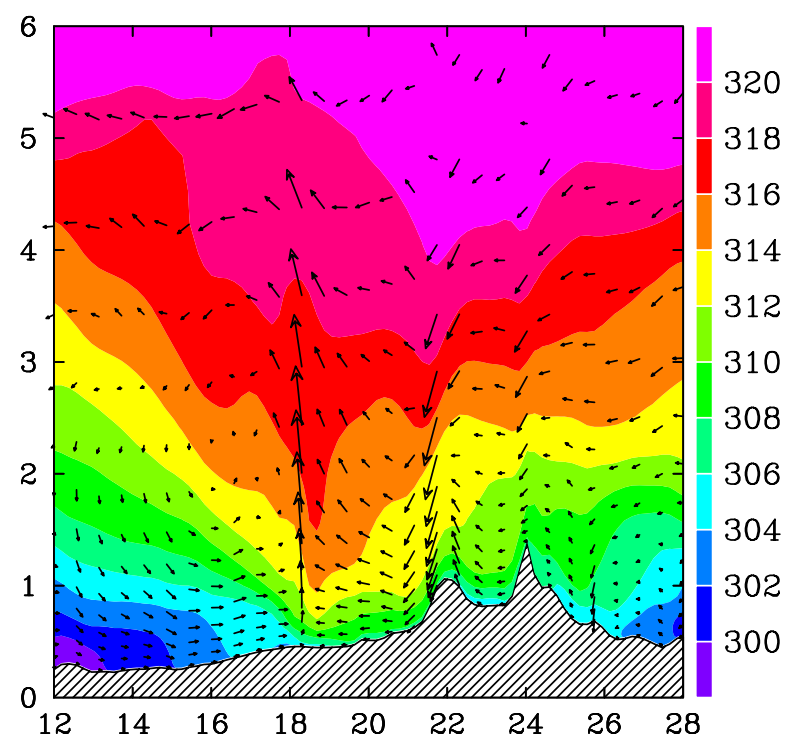

(b)

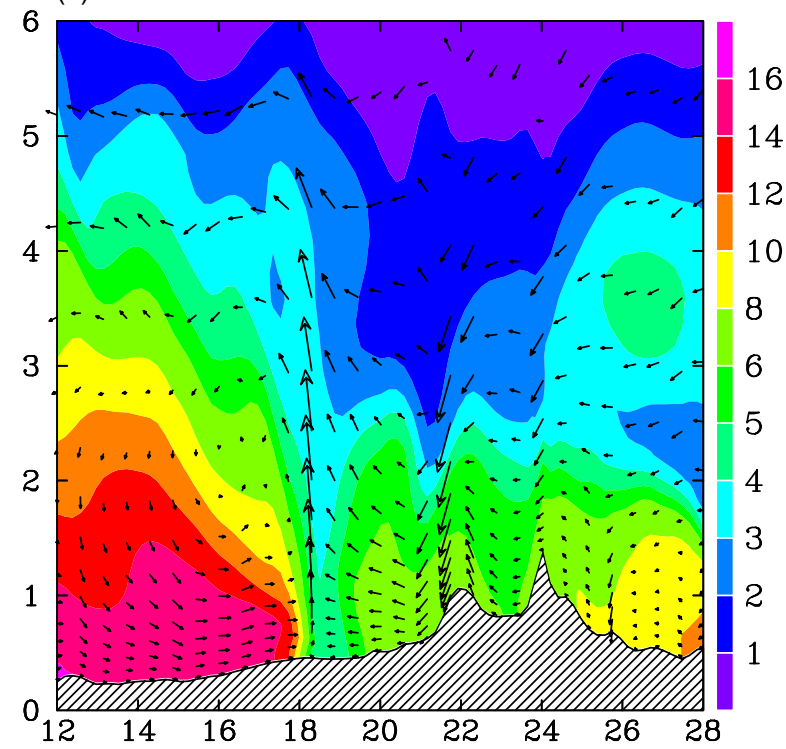

Figure 2. Vertical cross-section extracted from ECMWF analysis on 7 July 2006 at 0600 UTC along an extension of the F/F20 flight track to the north $\left(12^{\circ} \mathrm{N} ; 1^{\circ} \mathrm{E}-18^{\circ} \mathrm{N} ; 13^{\circ} \mathrm{E}\right.$, solid black line in Figure $\left.1(\mathrm{~d})\right)$, showing (a) potential temperature (colour, $\mathrm{K}$ ) and (b) water vapour mixing ratio (colour, $\mathrm{g} \mathrm{kg}^{-1}$ ), with along-cross-section winds (including vertical component) overlain. This figure is available in colour online at www.interscience.wiley.com/qj

\subsection{WIND and dropsonde data}

The wind speed and direction data acquired from the downward-pointing WIND system are shown in Figure 3(a) for the transect towards the north (0616 to 0718 UTC), and in Figure 3(b) for the transect back to Niamey (0719 to 0827 UTC). The two-dimensional cross-sections of potential temperature and water vapour mixing ratio fields along the flight track out of (back to) Niamey shown in Figure 4 were constructed using data from dropsondes 1 to 4 (4 to 10).

The near-surface wind reversal associated with the ITD is observed to be at around $18.7^{\circ} \mathrm{N}$ along the outgoing transect (Figure 3(a)), as determined from the WINDderived zero isotach of the wind component perpendicular to the flight track. The shape of the monsoon-harmattan interface (not just the ITD) stands out clearly in the WIND data as the region of very light winds separating the two opposing flows (Figure 3(a)). The WIND data stresses that the slope of the monsoon-harmattan interface was gentle near the leading edge of the monsoon flow, of the order of $17 \mathrm{~m} \mathrm{~km}^{-1}$. (The height of the monsoon layer top increased from 500 to $1700 \mathrm{~m}$ amsl between 18.7 and $\left.18^{\circ} \mathrm{N}\right)$. South of $18^{\circ} \mathrm{N}$, the monsoon-harmattan interface was almost horizontal. The depth of the southwesterly monsoon flow was of the order of $1.8 \mathrm{~km}$, away from the leading edge. The AEJ is clearly seen in the WIND and dropsonde data, extending throughout the entire aircraft leg, with the largest wind speeds below $6 \mathrm{~km}$ amsl. North of the ITD, WIND data indicate the existence of a thin near-surface layer of strong southeasterly winds $\left(12-14 \mathrm{~m} \mathrm{~s}^{-1}\right)$, separated from the northeasterly AEJ ( $16 \mathrm{~m} \mathrm{~s}^{-1}$ or more) by a layer of weaker winds $\left(8 \mathrm{~m} \mathrm{~s}^{-1}\right)$.
Isentropes within the monsoon flow (309 K and below) were observed to slope downwards with latitude (Figure 4(b)). A similar behaviour was observed for isentropes and contours of water vapour mixing ratio associated with the harmattan flow, both north of the ITD and above the monsoon. The monsoon flow was characterized by water vapour mixing ratio values of $9 \mathrm{~g} \mathrm{~kg}^{-1}$ or more (Figure 4(a)). The stratification in the AEJ was quite different from that of the monsoon and harmattan layers, potential temperature and water vapour mixing ratio being more mixed in the vertical.

On the return flight to Niamey, the thermodynamical structure of the atmosphere did not change significantly, with the notable exception of the location of the leading edge of the monsoon which was observed from WIND measurements to have slightly progressed north, i.e. to roughly $18.9^{\circ} \mathrm{N}$ (Figure $3(\mathrm{~b})$ ).

The progression speed of the leading edge was estimated to be approximately $10.5 \mathrm{~m} \mathrm{~s}^{-1}$, based on the precise determination of the location of the leading edge by WIND and the time at which it was detected. It was found to be close to the near-surface wind speeds derived from WIND and dropsonde 7, just behind the leading edge, as shown by Lowe et al. (2002). However, the measurements do not show a distinct maximum of winds just above the surface behind the leading edge, as expected from the wind structure in a density current. One reason could be that the monsoon density current is more diffuse than a two-fluid laboratory system. In addition, heating of the ground in the early morning hours helps to weaken the monsoon density current. The propagation of the leading edge was substantially slower than the maximum wind speed (of the order of $15 \mathrm{~m} \mathrm{~s}^{-1}$ ), observed several hundred kilometres behind it by WIND and dropsonde 9 . 

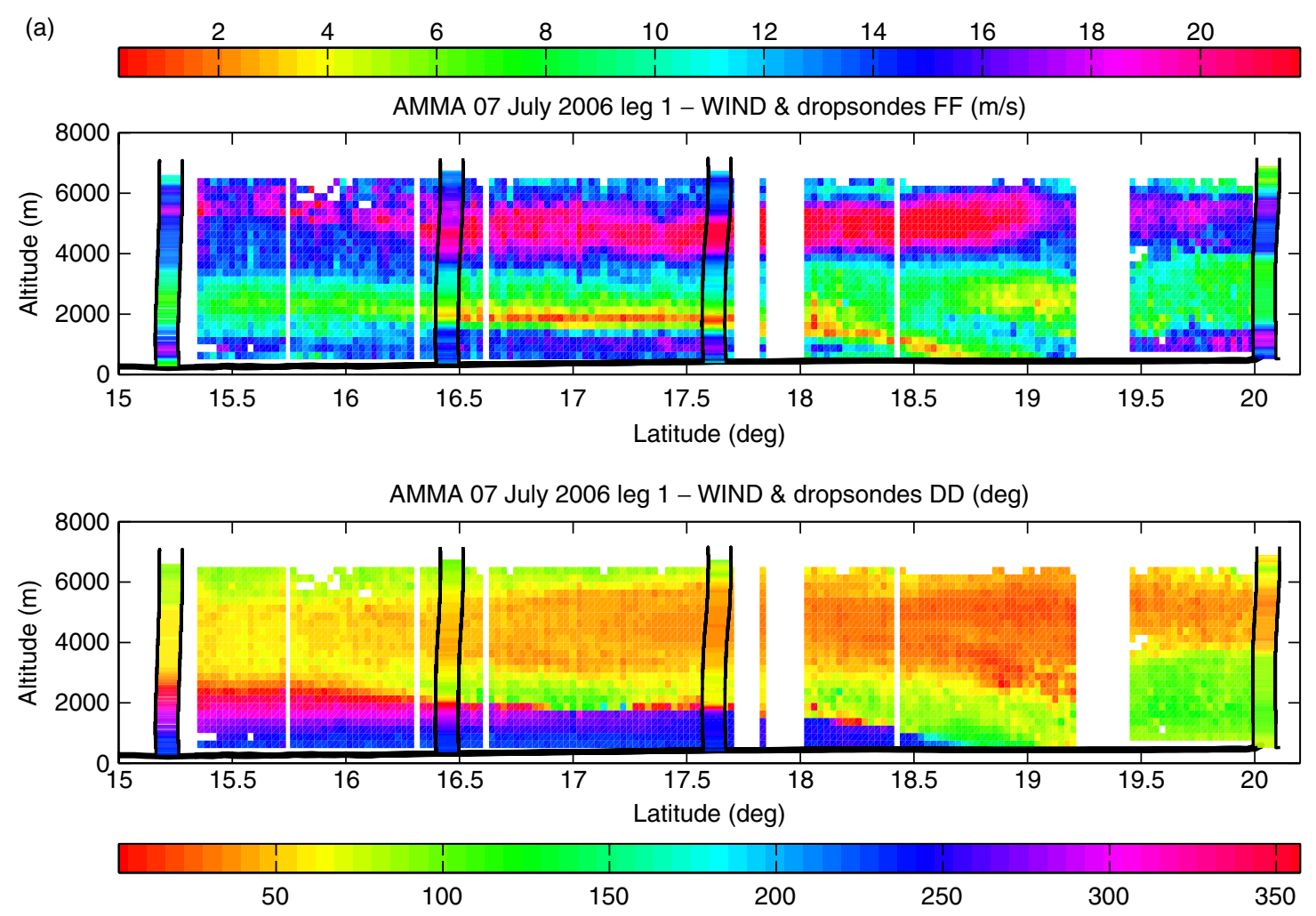

(b)

\begin{tabular}{|rrrrrrrrrr|}
2 & 4 & 6 & 8 & 10 & 12 & 14 & 16 & 18 & 20 \\
\hline 1 & 1 & 1 & $\mid$ & 1 & 1 & $\mid$ & & & \\
\hline
\end{tabular}

AMMA 07 July 2006 leg $2-$ WIND \& dropsondes FF $(\mathrm{m} / \mathrm{s})$
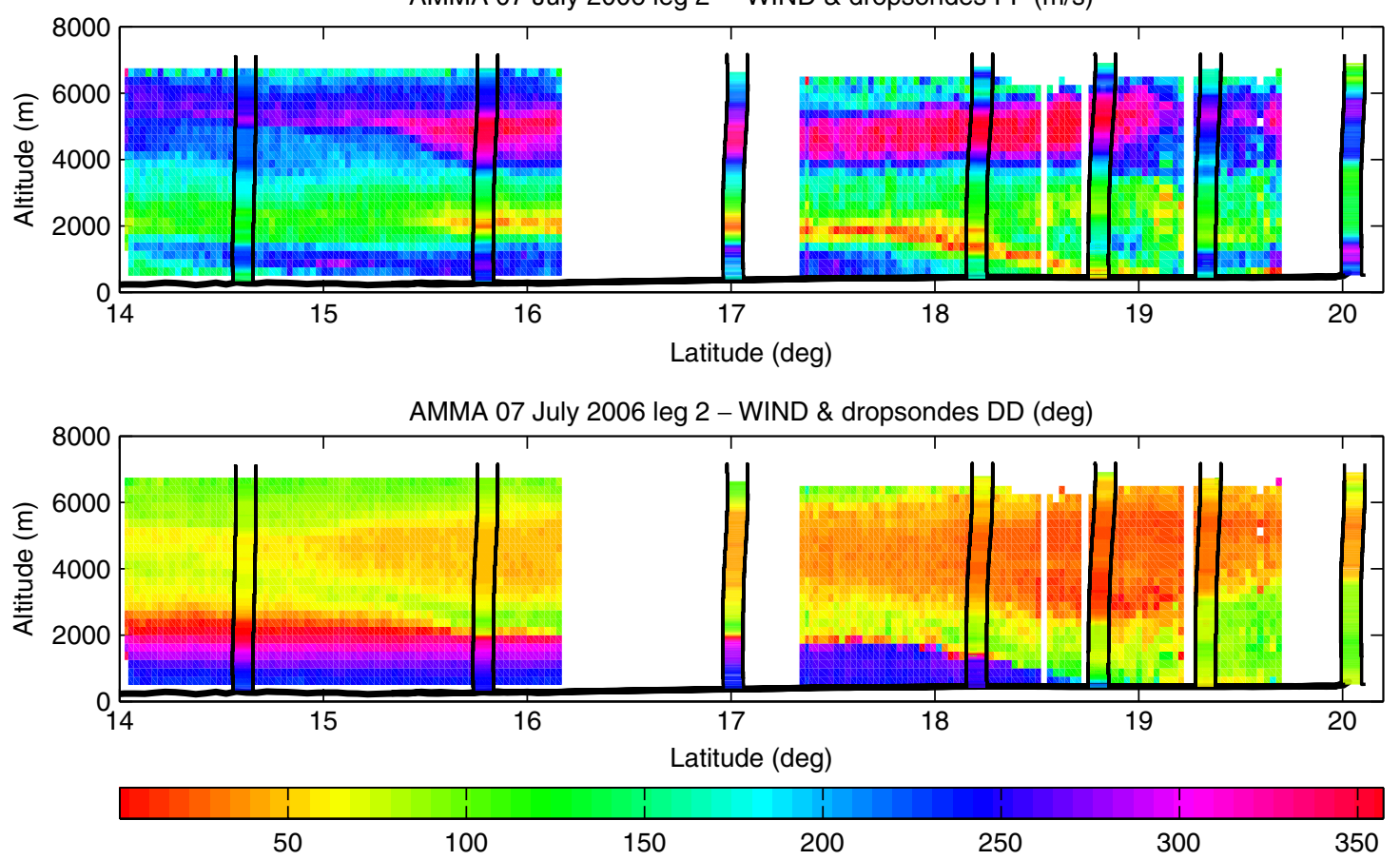

Figure 3. (a) Wind speed (top, $\mathrm{m} \mathrm{s}^{-1}$ ) and direction (bottom, degrees) derived from WIND on 7 July 2006 on the flight from Niamey, between 0616 and 0718 UTC. Wind speed and direction derived from dropsondes are overlain (between pairs of vertical solid black lines). Altitudes are amsl. (b) is as (a), but for the return flight to Niamey between 0719 and 0827 UTC. This figure is available in colour online at www.interscience.wiley.com/qj

The theoretical depth and the propagation speed of the monsoon density current were computed using Equations (2) and (3) using the near-surface measurements of pressure, virtual potential temperature, and air density from dropsonde 8 (within the cold air mass) and dropsonde 5 (within the warm air mass ahead of the leading edge). The pressure was corrected using the hydrostatic equation to account for the slight increase 

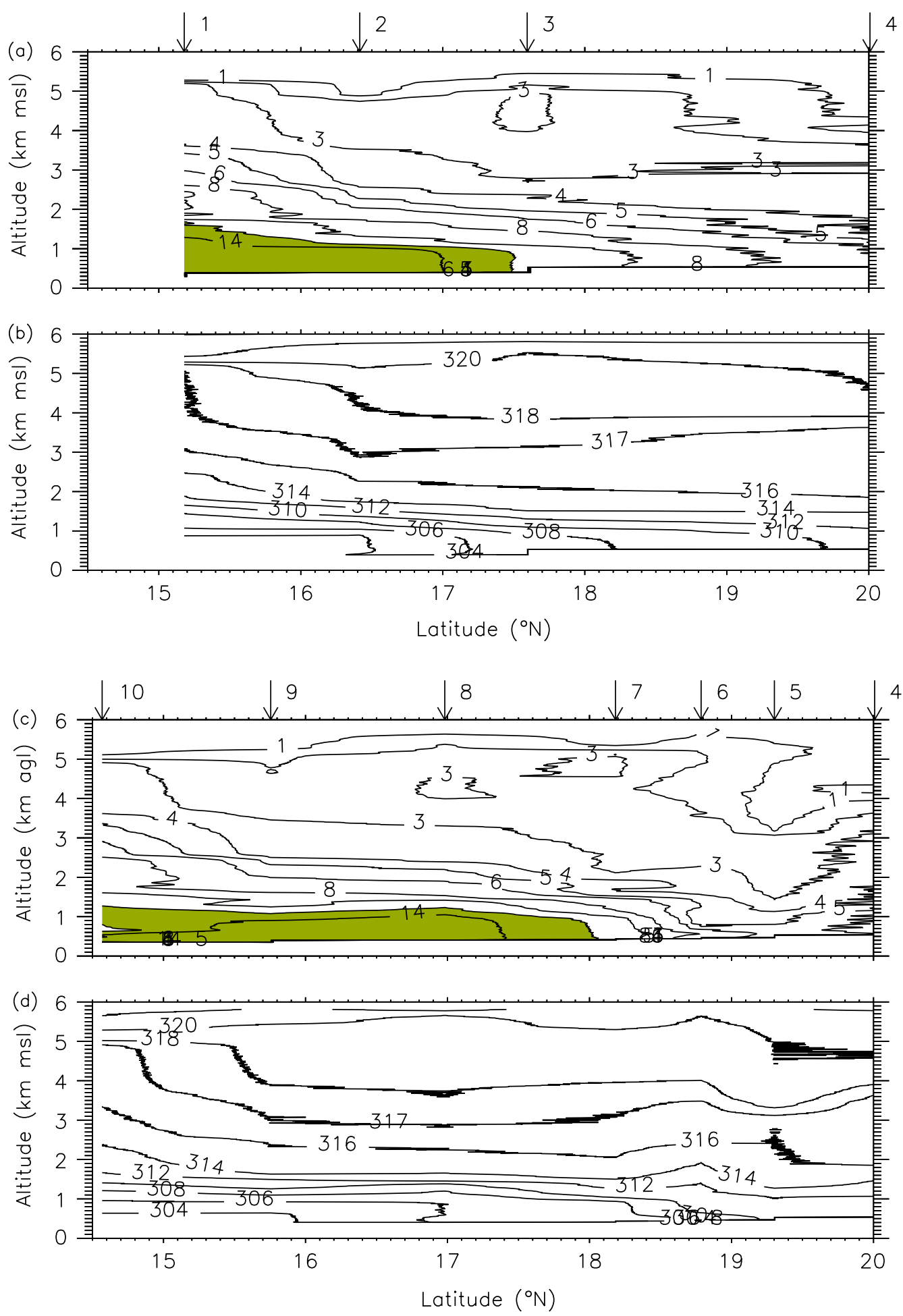

Figure 4. Vertical cross-sections of (a) water vapour mixing ratio and (b) potential temperature derived from dropsonde measurements on 7 July 2006, on the flight out of Niamey between 0614 and 0714 UTC. (c, d) are as (a, b), but for the flight back to Niamey between 0714 and 0820 UTC. The contour interval for water vapour mixing ratio is $1 \mathrm{~g} \mathrm{~kg}^{-1}$ between 1 and $6 \mathrm{~g} \mathrm{~kg}^{-1}$, and $2 \mathrm{~g} \mathrm{~kg}^{-1}$ between 6 and $14 \mathrm{~g} \mathrm{~kg}^{-1}$; the green area indicates regions where the mixing ratio is $>12 \mathrm{~g} \mathrm{~kg}^{-1}$. For potential temperature, the interval is $2 \mathrm{~K}$, with an additional contour at $317 \mathrm{~K}$. The arrows indicate the location of the dropsondes released along the transect, with the numbers as in Table I. This figure is available in colour online at www.interscience.wiley.com/qj

in altitude of the surface with respect to sea level. The theoretical propagation speed of the leading edge was estimated to range from 9.8 to $13.6 \mathrm{~m} \mathrm{~s}^{-1}$ for a Froude number ranging from 0.8 to 1.1 , in fair agreement with the estimate discussed previously. The theoretical depth of the monsoon was found to be $1480 \mathrm{~m}$, i.e. slightly less than the depth estimated from the WIND measurements (roughly $1800 \mathrm{~m}$ away from the head). This difference may be explained by the existence of significant vertical shear north of the monsoon leading edge (e.g. Figure 3), 
as density currents become deeper and propagate faster relative to the environmental flow as the shear increases (Xu, 1992).

\subsection{Comparison between ECMWF analyses and} observations

To facilitate the comparison with the observations along the flight track, Figure 5 shows the ECMWF analysis wind speed and direction, as well as water vapour mixing ratio and potential temperature from 14 to $20^{\circ} \mathrm{N}$, at 0600 UTC. ECMWF analysis should be representative of the average atmospheric state during aircraft operations.

Overall, there is good agreement between dropsonde, WIND observations and the ECMWF analyses along the track (Figure 5). The ECMWF analysis at 0600 UTC captured the main dynamical features well.

(a)

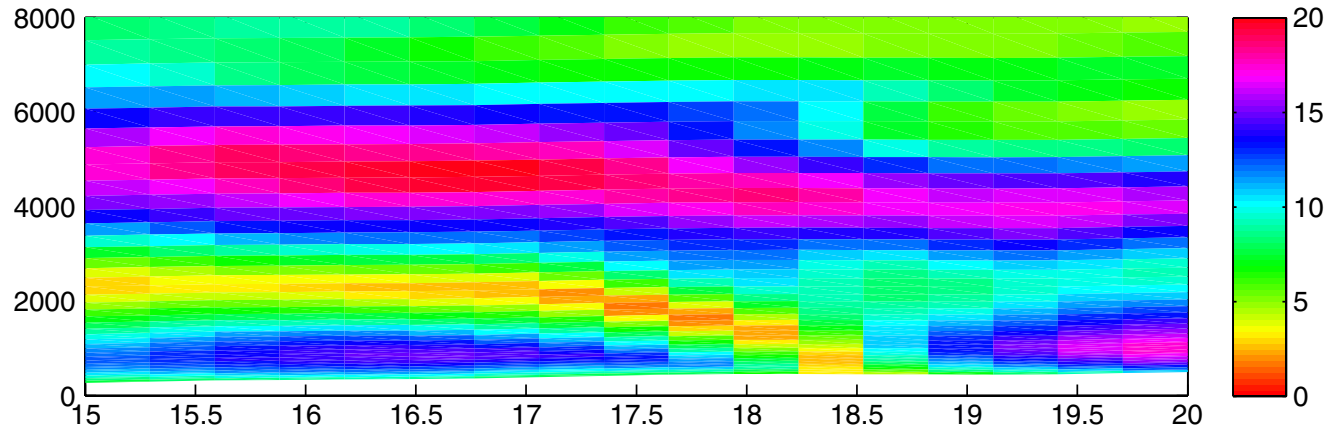

(b)

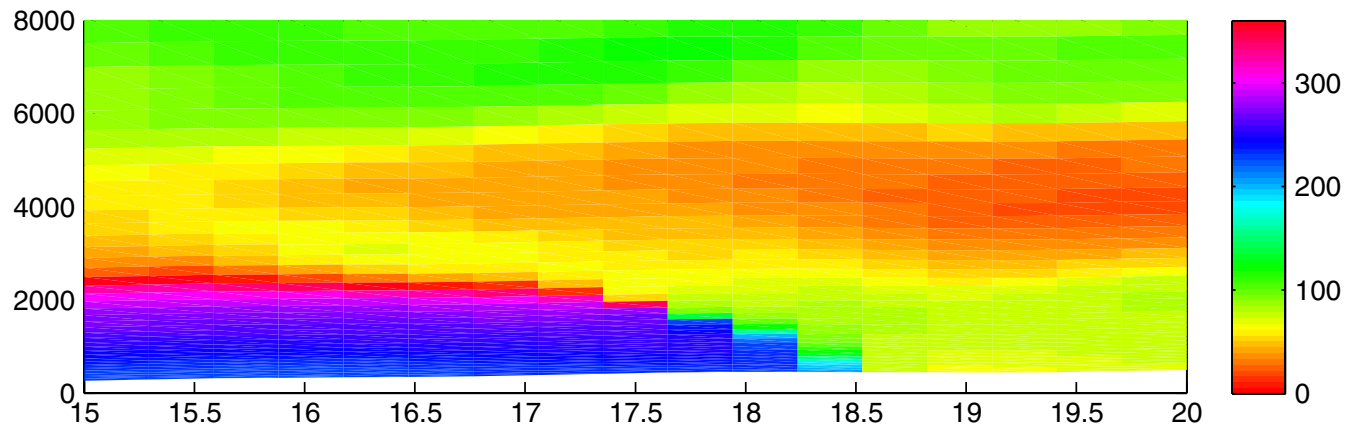

(c)

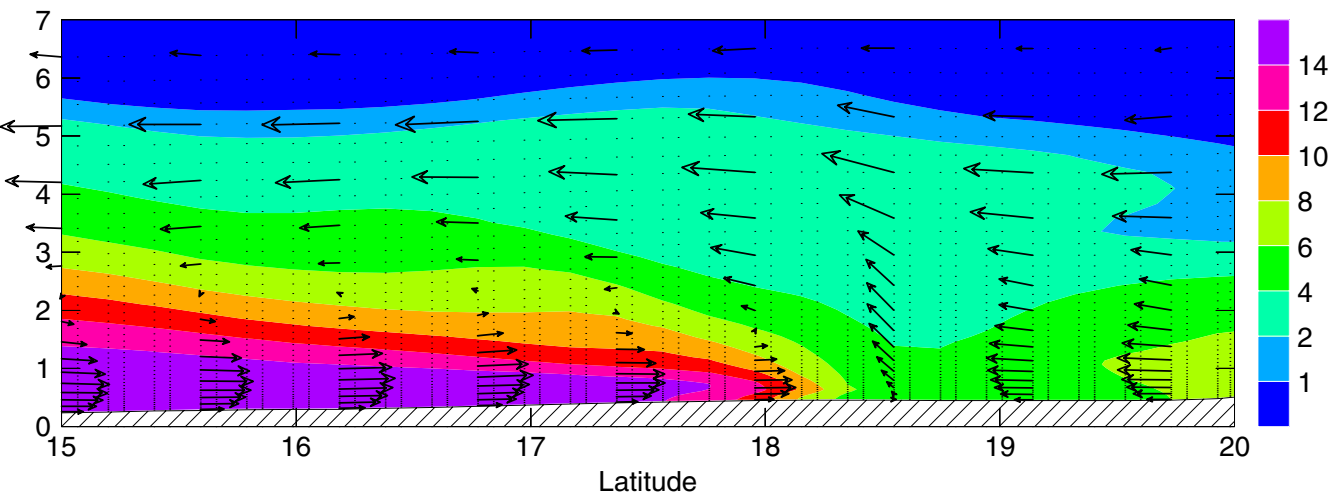

(d)

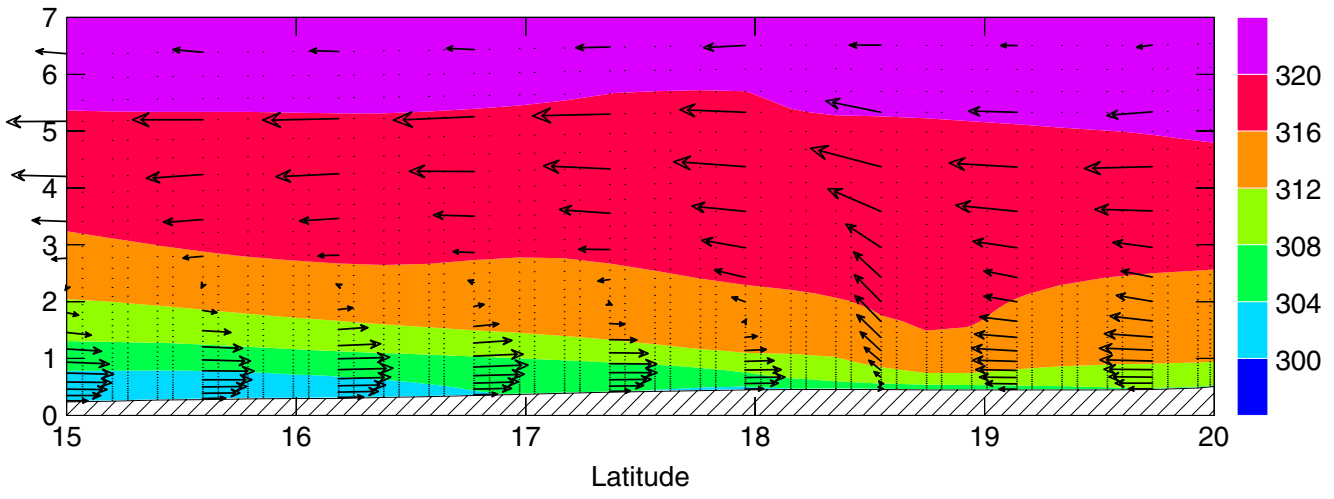

Figure 5. Vertical cross-sections of (a) wind speed $\left(\mathrm{m} \mathrm{s}^{-1}\right)$, (b) wind direction (degrees), (c) water vapour mixing ratio ( $\mathrm{g} \mathrm{kg}{ }^{-1}$ ), and (d) potential temperature (K) from ECMWF analysis on 7 July 2006 at 0600 UTC along the F/F20 flight track. Along-cross-section winds (including the vertical component) are overlain on (c) and (d). This figure is available in colour online at www.interscience.wiley.com/qj 
The intensities of the monsoon flow, of the AEJ and of the low-level jet north of the ITD are quite realistic (Figure 5(a)). The ITD, as determined by the lowlevel wind reversal, is found in very close agreement with that derived from WIND (Figure 3). On the other hand, the region of weak winds at the interface between the monsoon and the harmattan is seen to extend further south than in the WIND data (Figure 5(a)). The change in wind direction near the top of the monsoon layer south of $17.5^{\circ} \mathrm{N}$ is well reproduced by the ECMWF analysis (Figure 5(b)). The signature of the Hoggarrelated orographic perturbation in the water vapour mixing ratio (Figure 5(c)) and in the potential temperature fields (Figure 5(d)) are also well captured by the analysis. For instance, the intrusion of hot, dry air to the north seen in the analysis is evident in the dropsonde data, north of $19^{\circ} \mathrm{N}$ and above $4 \mathrm{~km}$ amsl (Figures 4(c) and (d), respectively). The structure and moisture content of the monsoon flow is found to be in agreement with the dropsonde observations. The monsoon and the atmosphere above are observed to be slightly cooler than in the analysis (Figure 5(d)). Nevertheless, the stratification

(a)

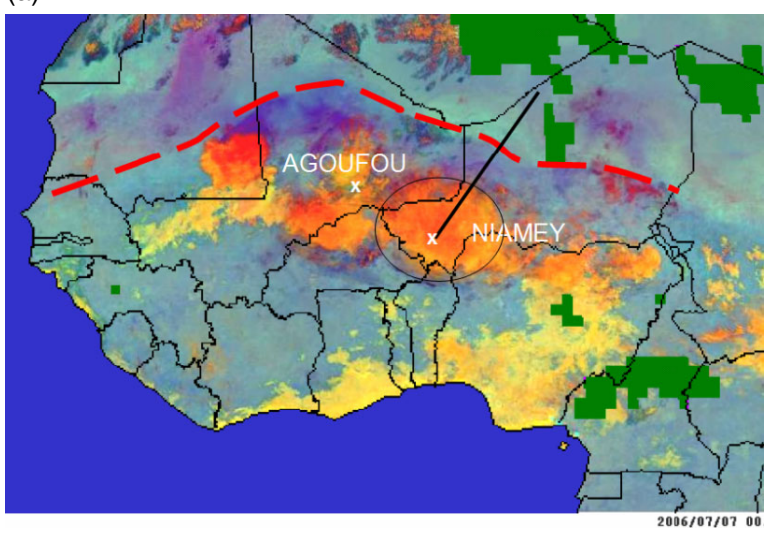

in the lower $7 \mathrm{~km}$ amsl along the flight track was very realistic, as for instance the steepening of the isentropic surfaces above the monsoon flow at $15.5^{\circ} \mathrm{N}$ or the shape of the isentropic surfaces in the ITD region.

\section{Dust mobilization, mixing and transport in the ITD region}

\subsection{Spaceborne observations}

Several areas with high dust load were observed over North and West Africa during the airborne operations as indicated from MSG/SEVIRI false-colour images (Figure 6). At 0645 UTC large dust storms (appearing pink or magenta in Figure 6(c)) were visible over Libya, Chad, Mauritania, Mali, Algeria and Niger. Three distinct types of dust storms can be seen, all being closely linked with the strong low-level winds shown in Figure 1(a): (a) over Mauritania, Mali and Niger, to the south of the ITD in connection with the strong turbulent winds along the leading edge of the monsoon acting as an intrusive density current, (b) over northern Mauritania and over

(b)

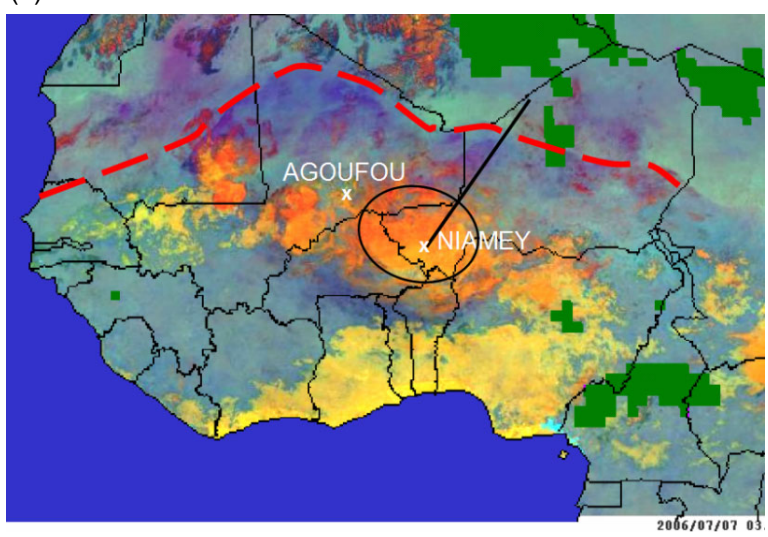

(c)

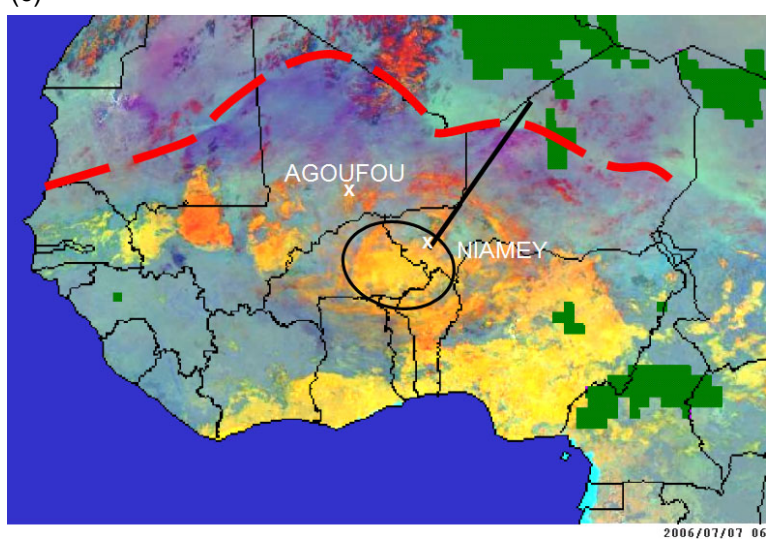

Figure 6. False-colour image constructed using 12.0 minus $8.7 \mu \mathrm{m}$ (red), 10.8 minus $8.7 \mu \mathrm{m}$ (green) and $10.8 \mu \mathrm{m}$ (blue) infra-red SEVIRI channel brightness temperatures on 7 July 2006 at (a) 0000 UTC, (b) 0330 UTC and (c) 0645 UTC. Dust appears pink or magenta, water vapour dark blue, thick high-level clouds red-brown, thin high-level clouds almost black and surface features pale blue or purple. Thin black lines indicate political boundaries. The bold black line indicates the F/F20 track. The orography as it appears in the ECMWF analysis at the $925 \mathrm{hPa}$ level is shown in green. The ellipse indicates the position of the MCS from which the northward-propagating density current observed in Figure 7 south of the monsoon leading edge emanated. The position of the ITD, marked by the bold red dashed line, is estimated from the dust plume's position and visual inspection of ECMWF wind fields at $925 \mathrm{hPa}$ at 0000 and $0600 \mathrm{UTC}$. This figure is available in colour online at www.interscience.wiley.com/qj 
Libya, in connection with the strong winds blowing from the Atlantic and the Mediterranean, respectively, and (c) over the Bodélé Depression, as well as over western Niger (west of the Airr), in the lee of the constriction between the Hoggar and the Tibesti massifs. The later storms were likely associated with orographic channelling of the harmattan flow. Note that the sharp colour contrast (purple to light blue) observed across the ITD is further enhanced by the water vapour loading south of the ITD as seen in the ECMWF analysis.

Animation of the SEVIRI colour composition images (e.g. http://loaamma.univ-lille1.fr/AMMA/MET/gall_ 2006.php) suggest that the dust storms associated with the leading edge of the monsoon flow propagated slowly northward between 0000 and 0600 UTC (Figure 6), before being blocked by the northerly winds. The northward progression of the dust storms during this period may also be related to the presence of density currents associated with the large MCSs over southwest Niger (Niamey area), Burkina Faso and at the Mali-Mauritania border at 0000 UTC. (The MCS appears in bright orange in Figure 6(a).) The density currents associated with such MCSs offer the most efficient mechanism for dust lifting (e.g. Flamant et al., 2007). As discussed in Flamant et al. (2007), the ITD region is likely to be perturbed by propagating density currents, which may modify its structure locally. The density current, associated with the MCS seen over Niamey at 0000 UTC, was observed at 0130 UTC on 7 July at Agoufou, Mali $\left(1.48^{\circ} \mathrm{W}\right.$; $15.34^{\circ} \mathrm{N}$ ). No SYNOP data were available on that day for stations in Niger, so that evidence of the northward propagation of the density current over northwest Niger cannot be demonstrated. Nevertheless, as discussed in the next section, there was indirect evidence of the presence of a propagating density current in the LEANDRE reflectivity data in the form of a dust plume lifted from the surface, as in Flamant et al. (2007). Density currents have been observed to propagate north over long distances, away from their parent MCSs (e.g. at least 8 hours in the case detailed by Flamant et al., 2007). Hence, even though the airborne observations shown here were acquired at a time when MCSs were decaying, a density current may still have propagated northward over Niger.

\subsection{Airborne observations of dust emission over Niger}

The high-resolution atmospheric reflectivity measurements made with the nadir-pointing LEANDRE 2 system are shown in Figure 7 (0602 to 0658 UTC) for the transect from Niamey and in Figure 8 (0718 to 0829 UTC) for the transect back to Niamey.
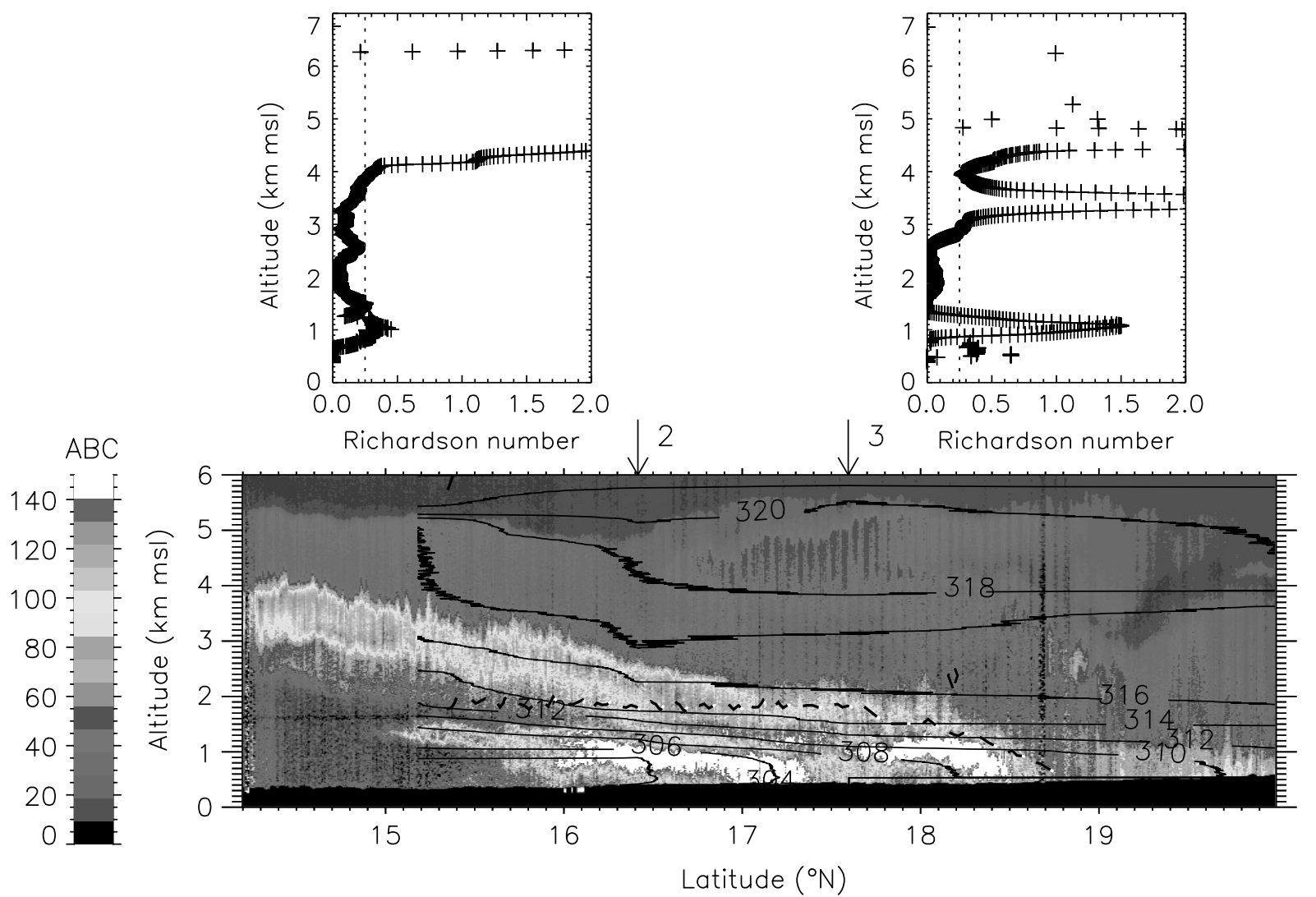

Figure 7. The cross-section shows LEANDRE 2-derived attenuated backscatter coefficient $(\mathrm{ABC}, \mathrm{colour})$ at $732 \mathrm{~nm}\left(\times 310^{-4} \mathrm{~km} \mathrm{sr}^{-1}\right)$ along the F/F20 track on 7 July 2006, on the flight out of Niamey between 0602 and 0658 UTC, with superimposed isentropes interpolated from dropsondes as in Figure 4. The bold black and white line corresponds to the zero isotach in the WIND-derived winds perpendicular to the flight track. The arrows indicate the location of the dropsondes (numbered as in Table I) released along the transect which were used to compute the profiles of bulk Richardson number shown in the upper part of the figure. The vertical dashed lines on these profiles represent the critical Richardson number value of 0.25 . 
Large near-surface values of atmospheric reflectivity were observed with LEANDRE 2 between 16.9 and $17.3^{\circ} \mathrm{N}$ (i.e. within the monsoon flow) as well as between 18.2 and $18.5^{\circ} \mathrm{N}$ (close to the leading edge of the monsoon flow) as seen in Figure 7. As discussed by Flamant et al. (2007), these high reflectivity values correspond to a large concentration of dust aerosols being eroded from the surface and subsequently lifted by the monsoon winds. A crucial criterion for the existence of a dust source is the availability of fine deflatable material, which can be lifted from the ground when the surface wind speed exceeds a certain threshold. This threshold has been shown to be quite variable (between 5 and $12.5 \mathrm{~m} \mathrm{~s}^{-1}$ ) in the western Sahara (Fernandez-Partagas et al., 1986). Consistent with this idea, the near-surface wind speed values derived from WIND and dropsonde 7 (8) were larger than $10 \mathrm{~m} \mathrm{~s}^{-1}\left(12 \mathrm{~m} \mathrm{~s}^{-1}\right)$, over the northern (southern) dust emission spot. Furthermore, the monsoon flow behaving like a density current, its leading edge is characterized by strong turbulent winds that can mobilize dust. To the south, the lifting is thought to be related to the passage of the density current, emanating from the MCS to the south, as discussed in Section 5.1. Turbulence associated with the density current can also explain the dust erosion at the surface. Nevertheless, this feature was quite transient, and the near-surface dust mobilization associated with the propagating density current was not observed as clearly on the flight back to Niamey (Figure 8).
As done previously for the monsoon flow, the theoretical depth and the propagation speed of the density current were computed using dropsonde 2 (within the cold air mass) and dropsonde 3 (within the warm air mass ahead of the leading edge). The theoretical propagation speed of the leading edge was estimated to range from 8.1 to $11.2 \mathrm{~m} \mathrm{~s}^{-1}$ for a Froude number ranging from 0.8 to 1.1 . The theoretical depth of the density current was found to be $1130 \mathrm{~m}$, i.e. slightly more than the depth estimated from the LEANDRE 2 measurements (roughly $1000 \mathrm{~m}$ away from the head, around $16^{\circ} \mathrm{N}$ ).

Two distinct plumes were observed to be associated with the high surface reflectivity mentioned above (Figure 7). The structure of the southern dust plume was strongly constrained by the shape of the isentropes (i.e. dust appeared to be lifted along the isentropes) with little or no transport of dust across the isentropes, and was observed to extend from roughly $17.1^{\circ} \mathrm{N}$ southward to $16^{\circ} \mathrm{N}$, reaching $1 \mathrm{~km}$ amsl. For the northern plume, dust was observed to be lifted southward along the isentropes between 18.35 and $16.6^{\circ} \mathrm{N}$, within the monsoon flow (i.e. below the WIND-derived isotach zero of the wind component perpendicular to the flight track; Figure 3(a)). South of $16.6^{\circ} \mathrm{N}$, enhanced reflectivity values are no longer exclusively observed within the monsoon flow, but also aloft. The presence of high aerosol concentrations above the monsoon layer top may be explained by either (i) turbulent mixing across the monsoon layer top or/and (ii) lateral isentropic transport of dust.

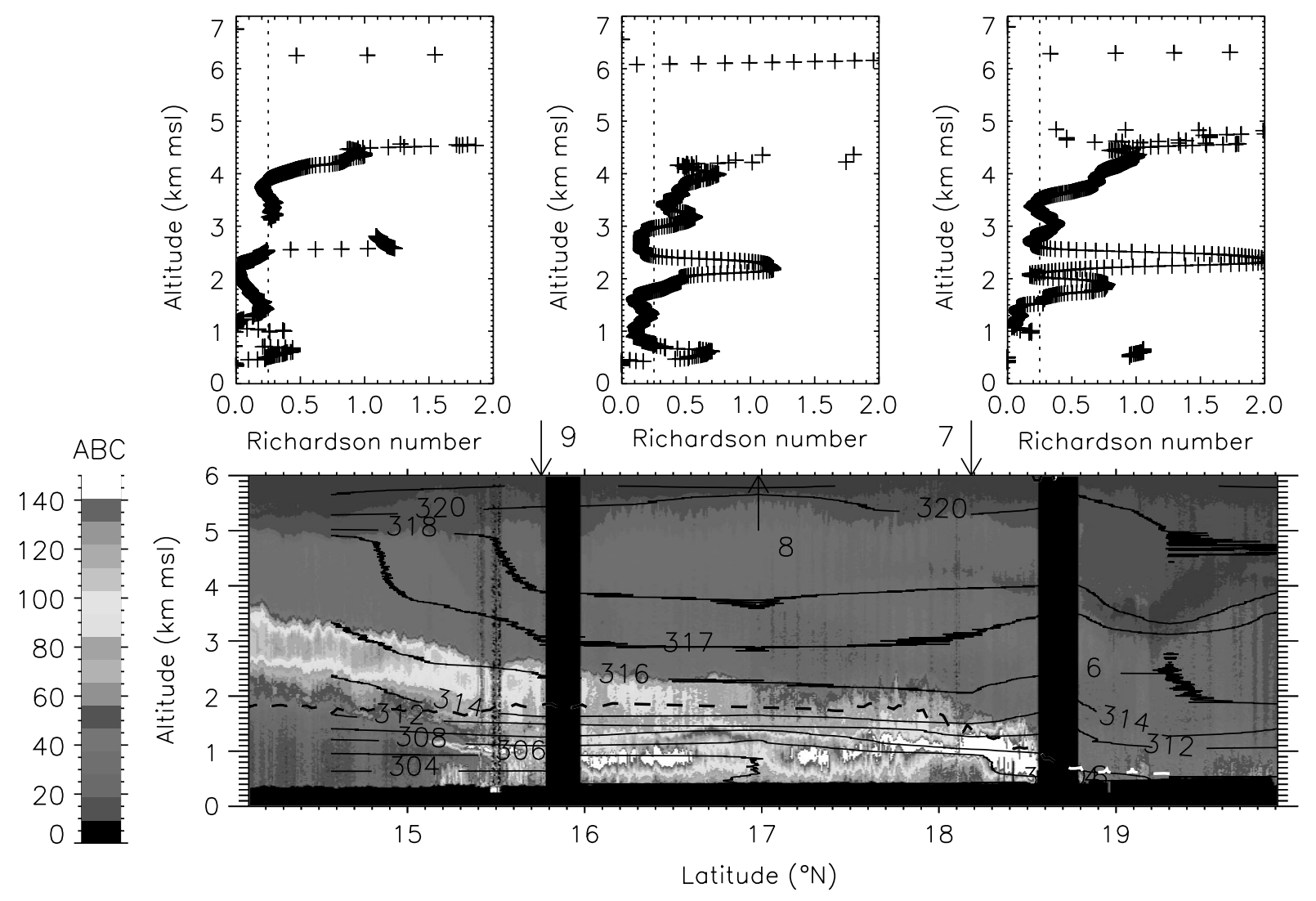

Figure 8. As Figure 7, but for the flight back to Niamey between 0718 and 0829 UTC. 
Bulk Richardson number profiles derived for dropsondes 2 and 3 (from Equation (1)) indicate the presence of a stable layer around $1 \mathrm{~km}$ amsl (within the strongly stratified monsoon), and above this layer, potential for mixing to higher levels mainly around $2 \mathrm{~km}$ amsl where the dust supposedly leaked out of the monsoon layer (Figure 7). Turbulent kinetic energy profiles derived from numerical simulations of this event revealed high values at $2 \mathrm{~km}$ amsl around $16.5^{\circ} \mathrm{N}$ (not shown). The sub-critical values of bulk Richardson number as derived from observations, together with high turbulent kinetic energy values seen in the simulation, strongly suggest that mixing across the monsoon-harmattan interface may be invoked to explain the origin of the high aerosol concentrations above the monsoon layer top. The critical Richardson number below which turbulence is assumed to occur, was set to 0.25 , although suggestions in the literature range from 0.2 to 1.0 (discussion by Jericevic and Grisogono, 2006). It is worth noting the reduction of the Richardson number values in the monsoon layer between dropsonde 3 and dropsonde 2, which suggests that the turbulence associated with the density current is strong even south of the leading edge. Likewise, we may also note a reduction of the Richardson number values between 3 and $4 \mathrm{~km}$ amsl. This suggests a potential for turbulence in the harmattan layer.

As mentioned before, there was evidence from the WIND data of lateral transport above the monsoon layer. A distinct region of winds oriented at angles between 45 and $90^{\circ}$ with respect to the flight track was observed between 16.5 and $17.3^{\circ} \mathrm{N}$ over a depth of $700 \mathrm{~m}$ above the monsoon layer top. (Evidence of this is seen in the wind direction, Figure 3(a).) The additional source of mechanical shear related to the presence of a core of transverse winds may have further enhanced the turbulence above the monsoon layer top and further favoured vertical transport of aerosol across the monsoon-harmattan interface. It is also thought to be the reason for the observed decrease of the Richardson number below the critical value between 3 and $4 \mathrm{~km}$ amsl as derived from dropsonde 2 .

Hence, even though there is strong evidence that the vertical mixing across the monsoon layer top is the mechanism responsible for the presence of enhanced reflectivity (and hence aerosol concentrations), lateral isentropic transport above the monsoon layer cannot entirely be discarded. As seen in Figure 6(c), dust storms were present over northern Niger, east of the Aïr range, and some of the dust lifted in this region may have been transported above the monsoon flow. Nevertheless the core of transverse winds was located slightly to the north of the core of enhanced reflectivity observed with LEANDRE 2. In all cases, these aerosols, once injected aloft, are transported southward with the harmattan along the isentropic surface $314 \mathrm{~K}$ in Figure 7.

Aloft, the air masses associated with the AEJ were associated with low reflectivity values, thereby suggesting that the AEJ was not advecting a significant amount of dust aerosols. South of $15^{\circ} \mathrm{N}$, low reflectivity values were associated with the monsoon flow, most likely due to the lack of fine deflatable material at the surface and/or enhanced soil moisture. North of the ITD, above $1 \mathrm{~km}$ amsl and below the AEJ, reflectivity values suggest low aerosol content. The larger reflectivity values (and hence aerosol concentration) below $1 \mathrm{~km}$ amsl are likely linked to the shallow easterly jet seen in the WIND data north of $19^{\circ} \mathrm{N}$ (Figure 3(a)). The low aerosol content to the north of the ITD as observed with LEANDRE 2 is in broad agreement with the MSG/SEVIRI colour composition image shown in Figure 6(c).

On the return flight to Niamey, and in spite of the rather short time difference separating the two transects, several key features were observed to have changed significantly. The region of large surface reflectivity values behind the monsoon leading edge was displaced to the north (Figure 8), consistent with the displacement of the ITD discussed in the previous section. The structure of the associated dust plume was strongly constrained by the shape of the isentropic surface $308 \mathrm{~K}$ within the monsoon i.e. below the WIND-derived zero isotach of the wind component perpendicular to the flight track (Figure 8). The dust plume generated by the density current to the south (Figure 7) is still observed between 16 and $16.6^{\circ} \mathrm{N}$ around $700 \mathrm{~m}$ amsl. However, near-surface dust mobilization was no longer observed in Figure 8. This could be due to the fact that the density current had weakened over time or had moved away from the crosssection. Other possible explanations could be that (i) the density current had passed over a localized source and there are no longer deflatable sediments available to be mobilized at its new position, or (ii) the local source was limited in its supply of erodible sediments.

A distinct layer of enhanced reflectivity values was still observed above the monsoon layer top, south of $17^{\circ} \mathrm{N}$ (Figure 8, south of dropsonde 8). The core of winds oriented at angles between 45 and $90^{\circ}$ with respect to the flight track was still observed between 16 and $17^{\circ} \mathrm{N}$ above the top of the monsoon layer (not shown). Hence mechanical shear is again likely responsible for the mixing across the monsoon layer top of the dust mobilized at the leading edge of the monsoon layer and transported southward below the monsoon-harmattan interface by the circulation in the head of the density current. To the north (i.e. location of dropsondes 7 and 8), mixing is still possible, but is most likely getting weaker as evidenced by the super-critical Richardson number values above $2 \mathrm{~km}$ amsl, together with the lack of enhanced LEANDRE-derived reflectivity above $2 \mathrm{~km}$ amsl in this region. The southward transport of dust above the monsoon layer with the harmattan was again observed in Figure 8. Interestingly, super-critical values of the Richardson number are observed just above the high reflectivity layer (see Richardson number profile derived from dropsonde 9 in Figure 8), possibly explaining why the aerosols leaking out of the monsoon layer south of dropsonde 8 did not mix to higher altitudes. 


\section{Discussion and conclusions}

Near-dawn airborne lidar and dropsonde observations made during an ITD survey mission in the framework of the AMMA SOP have been used to investigate dust mobilization, lifting and transport associated with the monsoon and harmattan flows in the ITD region. While dust storms are often observed from space to be associated with the leading edge of the monsoon flow at night-time, such satellite measurements with passive instruments can only provide vertically integrated information. This study presents the first lidar and dropsonde measurements made in this region, and provides insights into the mechanisms responsible for the observed vertical distribution of dust in connection with the monsoon dynamics. The high nearsurface winds and the turbulence at the leading edge of the monsoon flow (behaving as an intrusive density current) are responsible for dust mobilization. The circulation in the head of the monsoon density current then lifts the mobilized dust towards the wake along an isentropic surface. Likewise, the dust mobilized south of the ITD in connection with a density current issued of a MCS located over southwest Niger was lifted along an isentropic surface but remained confined within the monsoon flow.

To the north of the ITD, the stable stratification prevented the lifted dust from reaching altitudes at which it could be transported over long distances by the harmattan. (It is acknowledged, however, that this stratification will disappear in the course of the day and allow mixing throughout the PBL depth.)

Only the dust mobilized close to the leading edge could be lifted along the isentropic surfaces for a few hundred kilometres, before experiencing transport across the top of the monsoon layer and being advected southward over long distances by the harmattan. The mixing across the monsoon-harmattan interface was favoured by the turbulence associated with mechanical shear above the monsoon layer top, as suggested by an analysis of the bulk Richardson number profiles derived from dropsonde measurements.

Even though the existence of mechanical shear above the monsoon layer played a key role in favouring the mixing of dust across the top of the monsoon layer and southward transport by the harmattan for this particular case, the most significant mechanism highlighted by this study is the mobilization and lifting of dust at the leading edge of the monsoon flow, due to its density currentlike characteristics. Regardless of the role of shear above the monsoon layer, the strong mixing within the Saharan boundary layer occurring during the day allows the dust lifted at the leading edge of the monsoon flow to reach much higher levels, to be subject to long-range transport and to impact on the radiation budget over West Africa.

This study details a mechanism for dust mobilization and lifting at the monsoon leading edge that provides a possible explanation for the climatological results by Engelstaedter and Washington (2007). The peak in the annual dust cycle over West African dust hot spots is linked to small-scale high-wind events, typically found to be associated with density currents. The fact that the highest dust emissions are found in June is also consistent with the fact that the ITD is generally located over the Sahel during this period.

Relevant to the study by Engelstaedter and Washington (2007), it is also worth noting the good agreement between the high-resolution observations and the ECMWF analysis along the track for this particular casestudy, in broad agreement with the conclusions of Tompkins et al. (2005b) regarding the model quality.

Comparable observations were made during two other ITD survey missions on 3 and 10 July 2007, as well as with the spaceborne Cloud-Aerosol LIdar with Orthogonal Polarization (CALIOP) on board the Cloud-Aerosol Lidar and Infrared Pathfinder Satellite Observations (CALIPSO) satellite. This suggests that the analysis in this paper is representative of the dust mobilization at the leading edge of the monsoon flow. Because dust sources are widespread in the Sahel (e.g. Prospero et al., 2002), the mechanisms highlighted here could have important implications for the radiation budget over West Africa and on the West African Monsoon system during the months of June and July, i.e. when the ITD reaches the Sahel. One crucial objective for future studies is to assess the importance of dust emissions associated with the mechanism highlighted here, with respect to other source regions. While the net mass flux of dust emitted as the result of turbulence at the leading edge of the monsoon flow on a given day can most likely not be compared to that emitted in source regions such as the Bodélé Depression for a given discrete event, the overall emissions during the entire summer may be quite significant.

\section{Acknowledgements}

Based on a French initiative, AMMA was built by an international scientific group and is currently funded by a large number of agencies, especially from France, UK, US and Africa. It has been the beneficiary of a major financial contribution from the European Community's Sixth Framework Research Programme. Detailed information on scientific coordination and funding is available on the AMMA International web site http://www.ammainternational.org.

The authors wish to thank the SAFIRE (Service des Avions Français Instrumentés pour la Recherche en Environnement; www.safire.fr), the Institut Géographique National (IGN; www.ign.fr) and the Division Technique of the Institut National des Sciences de l'Univers (DT/INSU; www.dt.insu.cnrs.fr) for preparing and delivering the research aircraft (Falcon 20/F-GBTM) and the airborne instruments in a timely manner for the AMMA SOP. The deployment of the DLR Falcon aircraft during AMMA was partly funded by DLR and the authors wish to thank the professional support and operation of the aircraft by the DLR flight facility. They also wish to thank the AMMA Operation Centre and their 
partners across West Africa for smoothing out many aspects of the airborne operations. The authors are grateful to D. Bruneau and P. Genau (Service d'Aéronomie), F. Blouzon, A. Abchiche, D. Chaize, and N. Amarouche (DT/INSU) for re-fitting and operating the LEANDRE 2 system in the F/F20. Special thanks to A. Gribkoff, R. Cailloux and M. Laurens (SAFIRE) for operating the AVAPS dropsonde system. The authors wish to thank P. Drobinksi, P. Delville, M. L. Denneulin, B. Romand, E. Nagel, J. P. Aubagnac and F. Lavie for the preparation, deployment and operation of the WIND during AMMA, and the processing and analysis of the data. The authors wish to thank L. Gonzales and C. Deroo of LOA for making available SEVIRI colour composition images (www-loa.univ-lille1.fr) and Juan Cuesta of LMD for designing Figure 6 of this paper, and Jacqueline Duron of Laboratoire d'Aérologie for her help in improving Figures 1,2 and 5. The authors are grateful to the two anonymous reviewers for their helpful comments.

\section{References}

Alpert P, Ganor E. 1993. A jet stream associated heavy dust storm in the western Mediterranean. J. Geophys. Res. 98: 7339-7349.

Bruneau D, Quaglia P, Flamant C, Meissonnier M, Pelon J. 2001. The airborne lidar LEANDRE II for water-vapor profiling in the troposphere. I. System description. Appl. Opt. 40: 3450-3475.

Engelstaedter S, Washington R. 2007. Atmospheric controls on the annual cycle of North African dust. J. Geophys. Res. 112: D03103, DOI:10.1029/2006JD007195.

Evan AT, Heidinger AK, Knippertz P. 2006. Analysis of winter dust activity off the coast of West Africa using a new 24-year over-water advanced very high resolution radiometer satellite dust climatology. J. Geophys. Res. 111: D12210, DOI:10.1029/2005JD006336.

Fan S-M, Horowitz LW, Levy H II, Moxim WJ. 2004. Impact of air pollution on wet deposition of mineral dust aerosols. Geophys. Res. Lett. 31: L02104, DOI:10.1029/2003GL0118501.

Fernandez-Partagas J, Helgren DM, Prospero JM. 1986. 'Threshold wind velocities for raising dust in the western Sahara Desert'. ARO Technical Report. vol. 19684.3-GS. United States Army Research Laboratory, Army Research Office. (contract to University of Miami).

Flamant C, Chaboureau J-P, Parker DP, Taylor CM, Cammas JP, Bock O, Timouk F, Pelon J. 2007. Airborne observations of the impact of a convective system on the planetary boundary-layer thermodynamics and aerosol distribution in the intertropical discontinuity region of the West African Monsoon. Q. J. R. Meteorol. Soc. 133: 1175-1189.

Goff RC. 1976. Vertical structure of thunderstorm outflows. Mon. Weather Rev. 104: 1429-1440.

IPCC. 2001. Climate Change 2001: The Scientific Basis. Cambridge University Press: Cambridge, UK

IPCC. 2007. Climate Change 2007: The Physical Science Basis. Cambridge University Press: Cambridge, UK

Jankowiak I, Tanré D. 1992. Satellite climatology of Saharan dust outbreaks: Method and preliminary results. J. Climate 5: 646-656.

Jericevic A, Grisogono B. 2006. The critical bulk Richardson number in urban areas: Verification and application in a numerical weather prediction model. Tellus 58A: 19-27.

Knippertz P, Deutscher C, Kandler K, Müller T, Schulz O, Schütz L. 2007. Dust mobilization due to density currents in the Atlas region: Observations from the Saharan Mineral Dust
Experiment 2006 field campaign. J. Geophys. Res. 112: D21109, DOI:10.1029/2007JD008774.

Knippertz P, Fink AH. 2006. Synoptic and dynamic aspects of an extreme springtime Saharan dust outbreak. Q. J. R. Meteorol. Soc. 132: $1153-1177$

Koch SE, Dorian PB, Ferrare R, Melfi SH, Skillman WC, Whiteman DC. 1991. Structure of an internal bore and dissipating gravity current as revealed by Raman lidar. Mon. Weather Rev. 119: $857-887$

Lavaysse C, Flamant C, Janicot S, Parker DJ, Lafore J-P, Sultan B, Pelon J. 2008. Seasonal evolution of the West Africain heat low: A climatological perspective. Clim. Dyn. submitted.

Lowe RJ, Linden PF, Rottman JW. 2002. A laboratory study of the velocity structure in an intrusive gravity current, J. Fluid Mech. 456: 33-48.

Prospero JM, Ginoux P, Torres O, Nicholson SE, Gill TE. 2002. Environmental characterization of global sources of atmospheric soil dust identified with the nimbus 7 total ozone mapping spectrometer (TOMS) absorbing aerosol product. Rev. Geophys. 40(1): 1002, DOI:10.1029/2000RG000095.

Redelsperger J-L, Thorncroft CD, Diedhiou A, Lebel T, Parker DJ, Polcher J. 2006. African Monsoon Multidisciplinary Analysis: An international research project and field campaign. Bull. Am. Meteorol. Soc. 87: 1739-1746.

Reible D, Simpson JE, Linden PF. 1983. The sea breeze and gravitycurrent frontogenesis. Q. J. R. Meteorol. Soc. 119: 1-16.

Reitebuch O, Werner C, Leike I, Delville P, Flamant PH, Cress A, Engelbart D. 2001:. Experimental validation of wind profiling performed by the airborne $10.6 \mathrm{~m}$ heterodyne Doppler lidar WIND. J. Atmos. Oceanic Technol. 18: 1331-1344.

Schepanski K, Tegen I, Laurent B, Heinold B, Macke A. 2007. A new Saharan dust source activation frequency map derived from MSG-SEVIRI IR channels. Geophys. Res. Lett. 34: L18803, DOI:10.1029/2007GL030168.

Simpson JE. 1987. Gravity currents: In the environment and the laboratory. John Wiley and Sons: New York and Chichester, UK.

Sterk G. 2002. Causes, consequences and control of wind erosion in Sahelian Africa: a review. Land Degradation \& Development 14 95-108.

Todd MC, Washington R, Raghavan S, Lizcano G, Knippertz P. 2008. Regional model simulations of the Bodélé low-level jet of northern Chad during the Bodélé Dust Experiment (BoDEx 2005). J. Climate in press.

Tompkins AM, Cardinali C, Morcrette J-J, Rodwell M. 2005a. Influence of aerosol climatology on forecasts of the African Easterly Jet. Geophys. Res. Lett. 32: L10801.

Tompkins AM, Diongue A, Parker DJ, Thorncroft CD. 2005b.. The African easterly jet in the ECMWF Integrated forecast system: 4DVar analysis. Q. J. R. Meteorol. Soc. 131: 2861-2886.

Washington R, Todd MC. 2005. Atmospheric controls on mineral dust emission from the Bodélé Depression, Chad: The role of the low level jet. Geophys. Res. Lett. 32: L17701, DOI:10.1029/2005GL023597.

Werner C, Flamant PH, Reitebuch O, Köpp F, Streicher J, Rahm S, Nagel E, Klier M, Herrmann H, Loth C, Delville P, Drobinski P, Romand B, Boitel C, Oh D, Lopez M, Meissonnier M, Bruneau D, Dabas AM. 2001. WIND Instrument. Opt. Eng. 40: 115-125.

Xu Q. 1992. Density currents in shear flows: A two-fluid model. $J$. Atmos. Sci. 49: 511-524.

Yoshioka M, Mahowald NM, Conley AJ, Collins WD, Fillmore DW, Zender CS, Coleman DB. 2007. Impact of desert dust radiative forcing on Sahel precipitation: Relative importance of dust compared to sea surface temperature variations, vegetation changes, and greenhouse gas warming. J. Climate 20: 1445-1467, DOI:10.1175/JCLI4056.1. 